\title{
Experimental approach to the importance of parasitism in biological conservation
}

\author{
Pierre Sasal $^{1,2, *}$, Patrick Durand ${ }^{1}$, Elisabeth Faliex ${ }^{1}$, Serge Morand ${ }^{1}$ \\ ${ }^{1}$ Laboratoire de Biologie Animale, UMR, CNRS 5555, Université de Perpignan, Avenue de Villeneuve, \\ 66860 Perpignan Cedex, France \\ ${ }^{2}$ University of Windsor, Department of Biological Sciences, Windsor, Ontario N9B 3P4, Canada
}

\begin{abstract}
Recolonisation of protected areas by new host species, and their parasites, or the translocation of individuals (accidentally or intentionally) to new locations may induce new host-parasite associations. Parasites are usually found to be less well-adapted and more virulent to newly colonized host species. Such new host-parasite associations may represent threats to the survival of the host populations. Our study compared the reaction of a naive host facing a new parasite with the reaction of a host in a population already associated with that parasite. We collected 305 Pomatoschistus microps (Krøyer, 1838), second intermediate host of the digenean Labratrema minimus (Stossich, 1887), from 4 regions around Europe. The fish were experimentally exposed to the parasite strain endemic to one of these regions. The initial step consisted of evaluating the genetic variation among the different fish populations. The genetic results, based on isozyme electrophoresis, revealed a significant differentiation among the populations studied. The second step determined both the quantitative and qualitative success of infestation of the different host populations. Our results show that there is no quantitative difference between sympatric host-parasite success and allopatric success. However, at the ultrastructural level, sympatric infection appears to be more successful. The results are discussed in terms of the local adaptation of host-parasite associations and the consequences to biological conservation.
\end{abstract}

KEY WORDS: Fish · Parasite - Local adaptation - Biological conservation - Translocation - Digenean · Labratrema minimus · Pomatoschistus microps

\section{INTRODUCTION}

Conserving biological diversity has become one of the most important ecological goals over the last $20 \mathrm{yr}$. Numerous protected areas have been created to protect in situ biological diversity at both the species and gene level. Although too few in number and of limited overall area (Moyle \& Leidy 1992), protected areas have 3 main functions: (1) to maintain species-rich areas free of all exploitation; (2) to maintain sufficient individuals of an endangered species to ensure a viable population capable of recolonizing surrounding, unprotected zones; (3) to enable overexploited or displaced species to recolonize their habitat (Harmelin 1987, Francour 1994, Dufour et al. 1995).

•E-mail: sasal@univ-perp.fr
In addition to the creation of protected areas, there are other methods of conserving diversity that involve the transfer of individuals from regions with viable populations to regions where that species is rare or absent (Konstant \& Mittermeier 1982, Minckley 1995). Generally, such manipulations are now much less frequently considered or very carefully implemented. Intentional transfer of species is only carried out when the genetic history of the introduced individuals, the reasons for the disappearance of the earlier population, the field conditions, and the densities of interacting species (i.e. any local population that may still be present, predators and prey) are very well known (Kleiman 1989, Lindburg 1992, Lodge et al. 1998). During transfer of protected species or of species for aquaculture, one of the biggest problems is to anticipate the possible effects of parasites accidentally introduced with the transfer of the host species (Calvo-Ugarteburu 
\& McQuaid 1998). Parasites may affect their host differently in a different environment; they may also colonize new hosts among the resident indigenous species. Several examples of unwanted introduction of parasites and their dramatic effects on natural populations have been reported (Bauer \& Hoffman 1976, Dwyer et al. 1990, Viggers et al. 1993). Moreover, it has been shown that such a new parasitic relationship can evolve rapidly and nullify the success of the introduction (Dwyer et al. 1990, Carroll \& Boyd 1992).

The capacity of a parasite to successfully infect a host is mainly based on its ability to avoid host defensemechanisms. Intentional or accidental transfer of a host species would presumably alter the epidemiology of a parasitic relationship because of the changed environmental conditions. Modeling studies have shown parasite infectivity to be closely related to epidemiological factors (Claessen \& de Roos 1995), and that sympatric hosts and parasites should be more compatible than allopatric ones (Hamilton 1993, Frank 1994, Gandon et al. 1996, Morand et al. 1996). However, few studies have empirically demonstrated the greater compatibility of local associations compared to non-native associations (Vera et al. 1990, Ballabeni \& Ward 1993, Ebert 1994, Lively \& Jokela 1996). Moreover, it generally appears, in the case of invertebrates or vertebrates infected with macroparasites, that local adaptation is not ubiquitous (Soler \& Møller 1990, Briskie et al. 1992, Ballabeni \& Ward 1993, Grosholz \& Ruiz 1995, Dufva 1996, Lively \& Jokela 1996). Empirical studies have shown that in several cases a parasite may evolve through a minimal virulence value (Toft \& Karter 1990, Ewald 1995), resulting in optimal success of the hostparasite association.

The evolution of host-parasite systems has mostly been ignored in biological conservation (Scott \& Dobson 1989, McCallum \& Dobson 1995). Several case's of simultaneous host and parasite introduction have been reported for aquatic ecosystems (Hoffman 1970, Combes \& Le Brun 1990, Moravec 1992, Kennedy 1993, 1994). Host translocation may lead to 4 types of new host-parasite associations: (1) the establishment of a new host-parasite system in the area; (2) the establishment of a new parasite species in a zone where the local host population was previously free of the parasite (for example, because of the lack of an intermediate host in the case of indirect life-cycle parasite species or because of a locally resistant host population): (3) the establishment of a non-infected host population into a zone inhabited by the local population are infested by a parasite species; (4) the introduction of a host species into a zone inhabited by a generalist parasite species (a species able to complete its life cycle on several host species) to which it is vulnerable.
This paper aimed at determining if there is a differential reaction among several populations of a single fish species exposed to a single strain of a parasite species. The initial step determined patterns of genetic variation among populations of the host; the second step evaluated the host/parasite association of the different fish populations both quantitatively (epidemiologically) and qualitatively (histologically) at each sampling location.

\section{MATERIALS AND METHODS}

The host-parasite system. We examined the digenean bucephaliid Labratrema minimus (Stossich, 1887) and one of its second intermediate hosts, the gobiid fish Pomatoschistus microps (Krøyer, 1838). Maillard (1976) has reported the parasite's life cycle: The first intermediate host is the lamellibranch mollusc Cerastoderma glaucum (Bruguiere, 1789), and the final host is the sea bass Dicentrarchus labrax (Linnaeus, 1758). The eggs of the parasite are disseminated through the faeces of the final host. Miracidia are liberated, and infect the mollusc through skin penetration. Asexual reproduction occurs in the snail, and liberated cercariae actively penetrate the second intermediate host. These cercariae encyst as a metacercaria in the liver of this second intermediate host. The final host becomes infested by eating the second intermediate host.

Host samples. We collected more than 100 first intermediate hosts, Cerastoderma glaucum, in Salses-Leucate lagoon (Southern France $42^{\circ} 50^{\prime} \mathrm{N}, 03^{\circ} 00^{\prime} \mathrm{E}$ ), but only 3 of these shed cercariae. We can, therefore, assume limited genetic variability in the pool of infecting parasites in our experiments.

A total of 296 gobiids Pomatoschistus microps were captured live, with a seine net, at 4 different stations around Europe, during spring 1996 (Fig. 1). The fish were obtained from the (1) Salses-Leucate lagoon (Mediterranean Sea, Southern France: $42^{\circ} 50^{\prime} \mathrm{N}$, $03^{\circ} 00^{\prime} \mathrm{E}, \mathbf{n}=70$ ); (2) near Cadiz in the Guadalquivir river estuary (Atlantic Ocean, southern Spain: $36^{\circ} 30^{\prime} \mathrm{N}, 06^{\circ} 20^{\prime} \mathrm{W}, \mathrm{n}=100$ ); (3) Hendaye in the Chingudy Bay (Atlantic Ocean, south-west France: $43^{\circ} 30^{\prime} \mathrm{N}, 01^{\circ} 50^{\prime} \mathrm{W}, \mathrm{n}=73$ ) and (4) the island of Fehmarn (North Sea, northern Germany: $50^{\circ} 30^{\prime} \mathrm{N}$, $11^{\circ} 10^{\prime} E, n=53$ ).

Electrophoresis and genetic analysis. Skeletal muscle was dissected from fish, disrupted in $1 \mathrm{ml} 0.2 \mathrm{M}$ Tris- $\mathrm{HCl}$ buffer, and centrifuged for $10 \mathrm{~min}$ at $4000 \times g$ and $4^{\circ} \mathrm{C}$. The supernatant protein extract was then frozen and kept at $-80^{\circ} \mathrm{C}$ until required. Proteins were separated by horizontal starch gel electrophoresis according to Pasteur et al. (1987). Loci and alleles were designated according to Shaklee et al. (1990). The 
Table 1. Pomatoschistus microps. Protein systems examined, their loci and allelic variability. All systems were evaluated using skeletal muscle, and buffer systems were adapted according to Wallis \& Beardmore (1984) or Pasteur et al. (1987). TBE: trisborate, EDTA; TC: tris citrate; TCE: tris-citrate EDTA

\begin{tabular}{|c|c|c|c|}
\hline Protein system & Locus & Variability & Buffer \\
\hline Adenosine deaminase (EC 3.5.4.4) & ADA & Polymorphic & TC 8.0 \\
\hline Adenylate kinase (EC 2.7.4.3) & AK & Monomorphic & TC 8.0 \\
\hline Aspartate amino transferase (EC 2.6.1.1) & AAT & Polymorphic & TBE 8.0 \\
\hline Creatine kinase (EC 2.7.3.2) & $\begin{array}{l}\text { CK1 } \\
\text { CK2 }\end{array}$ & $\begin{array}{l}\text { Monomorphic } \\
\text { Monomorphic }\end{array}$ & $\begin{array}{l}\text { TC } 8.0 \\
\text { TC } 8.0\end{array}$ \\
\hline Fumarase (EC 4.2.1.2) & FUM & Polymorphic & TC 8.0 \\
\hline Guanine deaminase (EC $3.5,4.3)$ & GDA & Monomorphic & TC 8.0 \\
\hline Isocitrate dehydrogenase (EC 1.1.1.42) & IDH & Polymorphic & TC 8.0 \\
\hline Lactate dehydrogenase (EC 1.1.1.27) & $\begin{array}{l}\text { LDH1 } \\
\text { LDH2 }\end{array}$ & $\begin{array}{l}\text { Monomorphic } \\
\text { Monomorphic }\end{array}$ & $\begin{array}{l}\text { TCE } 8.7 \\
\text { TCE } 8.7\end{array}$ \\
\hline Malate dehydragenase (EC 1.1.1.37) & $\begin{array}{l}\text { MDH1 } \\
\text { MDH2 }\end{array}$ & $\begin{array}{l}\text { Polymorphic } \\
\text { Polymorphic }\end{array}$ & $\begin{array}{l}\text { TC } 8.0 \\
\text { TC } 8.0\end{array}$ \\
\hline Mannose phosphate isomerase (EC 5. 3. 1. 8) & MPI & Polymorphic & TCE 8.7 \\
\hline Peptidase leucyl glycyl glycine (EC 3. 4. 11-) & PEP B & Polymorphic & TC 8.0 \\
\hline Peptidase phenylalanyl leucine (EC 3. 4. 11-) & PEP E & Polymorphic & TC 8.0 \\
\hline Phosphogluconate deshydrogenase (EC 1.1 .1 .43 ) & PGD & Polymorphic & TCE 8.7 \\
\hline Phosphoglucoisomerase (EC 5. 3. 1.9) & $\begin{array}{l}\text { PGI1 } \\
\text { PGI2 }\end{array}$ & $\begin{array}{l}\text { Polymorphic } \\
\text { Polymorphic }\end{array}$ & $\begin{array}{l}\text { TCE } 8.7 \\
\text { TCE } 8.7\end{array}$ \\
\hline Phosphoglucomutase (EC 2.7.5.1) & $\begin{array}{l}\text { PGM1 } \\
\text { PGM2 }\end{array}$ & $\begin{array}{l}\text { Polymorphic } \\
\text { Polymorphic }\end{array}$ & $\begin{array}{l}\text { TC } 8.0 \\
\text { TC } 8.0\end{array}$ \\
\hline
\end{tabular}

most commonly observed allele in Salses-Leucate (the sympatric population) was assigned a mobility of 100 . Fifteen enzymes encoded by 20 putative loci were examined using 3 different buffer systems (Table 1). Within-sample variability was assessed by calculating the percentage of polymorphic loci at $95 \%$ level $P_{95}$, mean number of alleles per locus $(A)$, mean observed $\left(H_{\mathrm{o}}\right)$ and unbiased expected $\left(H_{\mathrm{e}}\right)$ heterozygosity per locus. Measures of allozyme variability were estimated

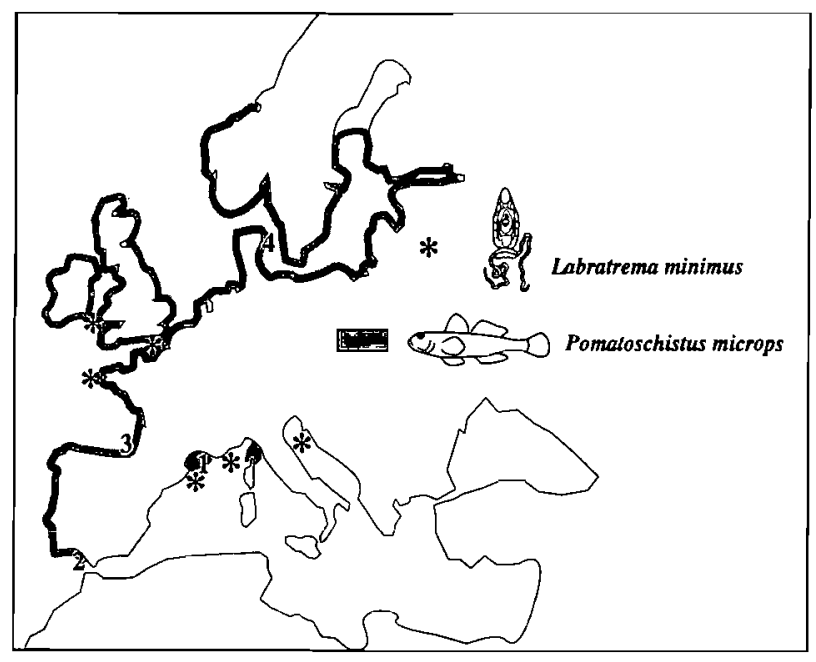

Fig. 1. Spatial distribution in western Europe of Pomatoschistus microps (according to Whitehead et al. 1986) and Labratrema minimus (according to Maillard 1976). 1: SalsesLeucate; 2 : Cadiz; 3: Hendaye; 4: Fehmarn using GENETIX v3.0 (Belkhir et al. 1996), and F-statistics estimators were calculated using GENEPOP v3.1 (Raymond \& Rousset 1995). Genetic distances between populations were calculated as $D=-\ln$ (1-theta) (Reynolds et al. 1983), and were displayed by UPGMA (unweighted pair-group method using arithmetic averages) (Sneath \& Sokal 1973).

Experimental infestations. Before the experiments, salinity was progressively adjusted to $28 \%$, corresponding to the salinity at which the molluscs shed the digenean cercariae. Fish were kept in an aerated aquarium in a climate-controlled room $\left(20^{\circ} \mathrm{C}\right)$, and were fed every other day with frozen brine shrimps (Artemia sp.). As the parasite species is reported to be ubiquitous along the coasts of Europe, we evaluated the initial level of infection of each population by counting encysted metacercaria in fish from each collection region prior to experimental infestation $(8,10$, 12 and 13 fishes were used for Fehmarn, Cadiz, SalsesLeucate and Hendaye, respectively). From each region, 30 fish (26 for Fehmarn) were experimentally infested. Individual fish were placed with 30 cercariae in $100 \mathrm{ml}$ seawater for $1 \mathrm{~h}$. Fish were necropsied $1 \mathrm{mo}$ later. Livers with encysted metacercariae were either dissected to quantitatively evaluate the infection success, or fixed in Bouin's solution (Martoja \& Martoja 1967) to evaluate the qualitative success of infection at the histological level.

Before dissection, the liver was immersed for $1 \mathrm{night}$ in a $0.25 \%$ solution of potassium hydroxide $(\mathrm{KOH})$. The following morning, the dissolved livers were fil- 


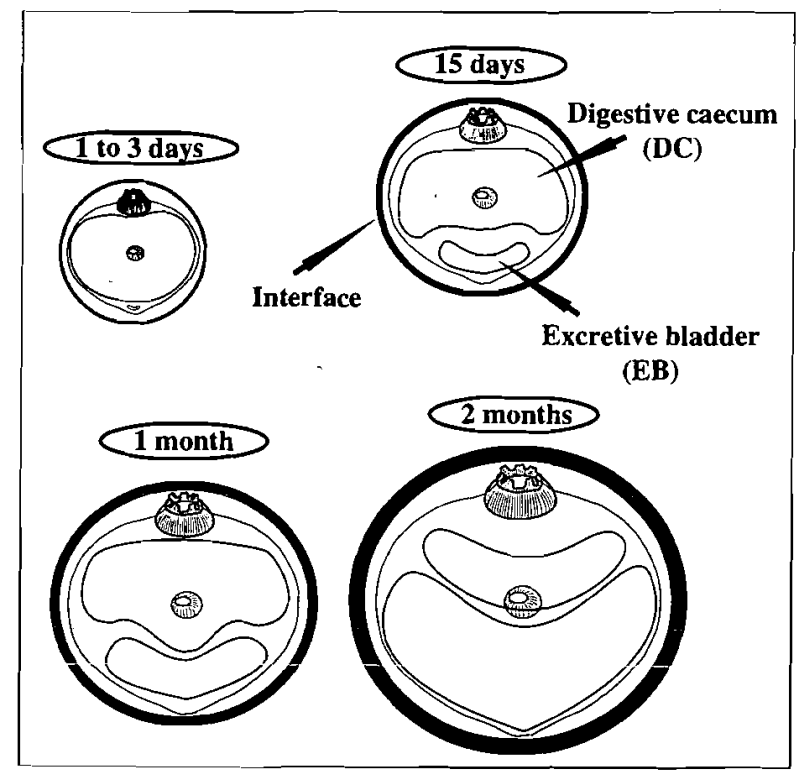

Fig. 2. Labratrema minimus. Schematic representation of metacercariae during first 2 mo of development (after Faliex 1990)

tered on a $40 \mu \mathrm{m}$ filter, and encysted metacercariae were stained with Lugol's solution and counted under a binocular microscope. We estimated infestation success for each individual $\left(S_{\text {ind }}\right)$ and for the population (taking into account the fish that died during the experiment) $\left(I_{\text {pop }}\right)$ :

$$
S_{\text {ind }}=\frac{N_{+30}-N_{0}}{30} \times 100
$$

and

$$
I_{\text {pop }}=\frac{\sum N_{+30}-N_{0}}{N_{\mathrm{HI}} \times 30} \times 100
$$

where $N_{+30}=$ total number of encysted metacercariae after infestation with 30 cercariae; $N_{0}=$ mean initial

Table 2. Pomatoschistus microps. Comparison of the biological factors between stations. SL: standard lengthi HSI: hepatosomatic index; K: condition factor (all factors $\pm \mathrm{SE}$ )

\begin{tabular}{|lccc|}
\hline Area & SL $(\mathrm{cm})$ & HSI $(\%)$ & $\mathrm{K}\left(10^{-3} \mathrm{~g} \mathrm{~cm}^{-3}\right)$ \\
\hline Salses-Leucate (1) & $3.50 \pm 0.03$ & $3.54 \pm 0.35$ & $9.8 \pm 0.2$ \\
Cadiz (2) & $3.18 \pm 0.03$ & $3.69 \pm 0.16$ & $10.8 \pm 0.2$ \\
Hendaye (3) & $3.77 \pm 0.04$ & $3.34 \pm 0.15$ & $10.6 \pm 0.2$ \\
Fehmarn (4) & $3.15 \pm 0.04$ & $4.44 \pm 0.38$ & $11.3 \pm 0.2$ \\
& & & \\
Mann-Whitney & $1>2 ; \mathrm{p}<0.001$ & All com- & $2>1 ; \mathrm{p}=0.01$ \\
& $1>4 ; \mathrm{p}<0.001$ & parisons & $4>1 ; \mathrm{p}<0.001$ \\
& $3>1 ; \mathrm{p}<0.01$ & NS & Other com- \\
& $3>2 ; \mathrm{p}<0.001$ & & parisons NS \\
& $3>4 ; \mathrm{p}<0.001$ & & \\
\hline
\end{tabular}

number of metacercariae in the considered population; $N_{\mathrm{HI}}=$ initial number of infected hosts.

For the histological study, livers were sectioned ( $7 \mu \mathrm{m}$ width) and stained according to the method of Martoja \& Martoja (1967). Histological evaluation of the infestation success for each population was limited to measuring the metacercarial development $1 \mathrm{mo}$ after infestation. Thus, we measured the volume of the digestive caecum and of the excretive bladder to evaluate metacercarial metabolic activity (Fig. 2). We also measured the volume of the metacercaria, the volume of the metacercarial cyst, and the width of the interface zone between the cyst and the fish's hepatic cells (Fig. 2). All measurements were made with an ocular micrometer, and volumes were estimated for a regular ovoid the formula $V=\left(\pi \times\right.$ length $\times$ width $\left.^{2}\right) / 6$.

We used non-parametric Mann-Whitney $U$-tests within one geographical zone or to compare 2 stations, and multiple-comparison Tukey-type tests for comparison among all 4 stations (Zar 1984). Discriminant analysis was performed on the histological measurements of the metacercarial cyst to calculate the Mahalanobis distances. A cluster-analysis similarity tree was performed on the Mahalanobis distances using the UPGMA method. A Mantel test between genetic and Mahalanobis distances was performed with 1000 permutations (Mantel 1967).

\section{RESULTS}

\section{Initial comparisons}

Size and condition of Pomatoschistus microps differed significantly among the 4 regions. Fish from Hendaye were largest (Mann-Whitney $U$-test, $\mathrm{p}<$ 0.001 ) (Table 2). The Salses-Leucate fish were significantly larger than those at the 2 remaining stations (Mann-Whitney $U$-test, $\mathrm{p}<0.001$ ) (Table 2). Hepatosomatic indexes did not differ significantly between sampling areas (Mann-Whitney $U$-test, $p>0.05$ ) (Table 2). Condition factors at Salses-Leucate were significantly lower than at Cadiz and Fehmarn (MannWhitney $U$-test, $\mathrm{p}<0.001$ ) (Table 2).

Within each region, fish samples taken to assess natural levels of infestation did not differ in size from the experimental fish (Mann-Whitney $U$-test, $\mathrm{p}>0.05$ for all stations). Hepatosomatic index and condition factors were not compared before and after the experiment, because during the month-long experiment food was provided at libidum. This would result in improved condition. 
Fish from the Salses-Leucate lagoon (sympatric association) were significantly more naturally infested than those from the other stations (multiple-comparison Tukey-type test, $\mathrm{p}<0.01$ for all stations). Fish from Cadiz were not naturally infected, even though Labratrema minimus is reported to be ubiquitous along the coasts of Europe (Maillard 1976).

\section{Genetic comparisons}

Genetic analysis revealed 14 scorable polymorphic loci (Table 3). Two loci (FUM and MDH1) were diagnostic between fish collected from the Mediterranean Sea (Salses-Leucate) and those from the other sampling areas. Locus MDH2 was not polymorphic (allele frequency $<5 \%$ ). The rate of polymorphism $\left(\mathrm{P}_{95}\right)$ among the remaining loci was high, ranging from 0.263 in Hendaye and Fehmarn to 0.421 in Cadiz (Table 4). Mean expected heterozygosity $\left(H_{\mathrm{e}}\right)$ ranged from 0.119 in Fehmarn to 0.179 in Cadiz, while the mean number of alleles per locus ranged from 1.53 to 2.16 in Fehmarn and Cadiz, respectively (Table 4 ).

There was a significant deviation from HardyWeinberg expectation for several loci within samples (positive $F_{1 \mathrm{IS}}$ see Table 5). Chi-square tests for homogeneity of allele frequencies over 10 polymorphic loci revealed significant differences at ADA, IDH, MPI, PEP2, PGI2 and PGM1 (Table 5). High genetic divergence was found between Salses-Leucate and all other samples $\left(F_{\mathrm{ST}}=0.635\right.$ for Cadiz, 0.657 for Hendaye, and 0.660 for Fehmarn). Inter-sample genetic differentiation $\left(F_{\mathrm{ST}}\right)$ between Cadiz, Hendaye and Fehmarn displayed lower values $\left(F_{S T}\right.$ Cadiz/Hendaye, 0.061 ; Cadiz/Fehmarn, 0.142; Hendaye/Fehmarn, 0.110).

\section{Quantitative experimental infestation success}

The individual infestation success $\left(S_{\text {ind }}\right)$ was higher for Salses-Leucate and Hendaye (multiplecomparison Tukey-type test, $\mathrm{p}<0.05$ ) (Table 6). When the number of dead fish (i. e. number of dead individuals due to the parasite infestation) was taken into account, success $\left(I_{\mathrm{pop}}\right)$ was significantly higher in Cadiz and lower in Fehmarn (multiplecomparison Tukey-type test, $\mathrm{p}<0.05$ ) (Table 6).

\section{Qualitative experimental infestation success}

The volume of the metacercaria, the volume of the digestive coecum, and the width of the interface were significantly greater in the sympatric association (Salses-Leucate) than in the allopatric
Table 3. Pomatoschistus microps. Allele frequencies at 14 polymorphic loci in samples from 4 areas. -: absent

\begin{tabular}{|c|c|c|c|c|c|}
\hline Locus & Allele & $\begin{array}{l}\text { Salses-Leucate } \\
\qquad(\mathrm{n}=57)\end{array}$ & $\begin{array}{c}\text { Cadiz } \\
(\mathrm{n}=61)\end{array}$ & $\begin{array}{c}\text { Hendaye } \\
(\mathrm{n}=69)\end{array}$ & $\begin{array}{c}\text { Fehmarn } \\
(n=50)\end{array}$ \\
\hline AAT & $\begin{array}{r}79 \\
89 \\
100\end{array}$ & $\begin{array}{c}- \\
0.053 \\
0.947\end{array}$ & $\begin{array}{c}1.000 \\
- \\
-\end{array}$ & $\begin{array}{c}1.000 \\
- \\
-\end{array}$ & $\begin{array}{c}1.000 \\
- \\
-\end{array}$ \\
\hline ADA & $\begin{array}{r}63 \\
75 \\
88 \\
95 \\
100 \\
107 \\
112 \\
122 \\
140\end{array}$ & $\begin{array}{c}0.070 \\
0.044 \\
0.219 \\
- \\
0.272 \\
0.009 \\
0.263 \\
0.123 \\
-\end{array}$ & $\begin{array}{c}- \\
- \\
0.008 \\
- \\
0.025 \\
- \\
0.057 \\
0.385 \\
0.525\end{array}$ & $\begin{array}{c}- \\
- \\
0.029 \\
- \\
0 . \overline{2} 17 \\
- \\
0.022 \\
0.275 \\
0.457\end{array}$ & $\begin{array}{c}- \\
- \\
- \\
- \\
- \\
- \\
- \\
0.580 \\
0.420\end{array}$ \\
\hline FUM & $\begin{array}{r}92 \\
100\end{array}$ & $\frac{-}{1.000}$ & $\begin{array}{c}1.000 \\
-\end{array}$ & $\begin{array}{c}1.000 \\
-\end{array}$ & $\begin{array}{c}1.000 \\
-\end{array}$ \\
\hline $\mathrm{IDH}$ & $\begin{array}{r}88 \\
100 \\
108\end{array}$ & $\begin{array}{c}0.018 \\
0.982 \\
-\end{array}$ & $\begin{array}{l}0.270 \\
0.443 \\
0.287\end{array}$ & $\begin{array}{l}0.210 \\
0.681 \\
0.109\end{array}$ & $\begin{array}{c}- \\
1.000 \\
-\end{array}$ \\
\hline MDH-1 & $\begin{array}{r}82 \\
100\end{array}$ & $\frac{-}{1.000}$ & $\begin{array}{c}1.000 \\
-\end{array}$ & $\begin{array}{c}1.000 \\
-\end{array}$ & $\begin{array}{c}1.000 \\
-\end{array}$ \\
\hline MDH-2 & $\begin{array}{r}47 \\
100\end{array}$ & $\begin{array}{l}0.018 \\
0.982\end{array}$ & $\begin{array}{c}1.000 \\
-\end{array}$ & $\begin{array}{c}1.000 \\
-\end{array}$ & $\begin{array}{c}1.000 \\
-\end{array}$ \\
\hline MPI & $\begin{array}{r}85 \\
90 \\
95 \\
100\end{array}$ & $\begin{array}{c}- \\
0.026 \\
0.079 \\
0.895\end{array}$ & $\begin{array}{l}0.033 \\
0.328 \\
0.451 \\
0.188\end{array}$ & $\begin{array}{c}- \\
0.159 \\
0.348 \\
0.493\end{array}$ & $\begin{array}{l}0.030 \\
0.100 \\
0.430 \\
0.440\end{array}$ \\
\hline PEP B & $\begin{array}{r}89 \\
100 \\
116\end{array}$ & $\begin{array}{c}- \\
1.000 \\
-\end{array}$ & $\begin{array}{c}- \\
0.902 \\
0.098\end{array}$ & $\begin{array}{c}0.007 \\
0.993 \\
-\end{array}$ & $\begin{array}{c}0.010 \\
0.990 \\
-\end{array}$ \\
\hline PEP E & $\begin{array}{r}65 \\
88 \\
100 \\
112\end{array}$ & $\begin{array}{c}- \\
0.053 \\
0.912 \\
0.035\end{array}$ & $\begin{array}{l}0.008 \\
0.008 \\
0.976 \\
0.008\end{array}$ & $\begin{array}{c}- \\
- \\
1.000 \\
-\end{array}$ & $\begin{array}{c}- \\
- \\
1.000 \\
-\end{array}$ \\
\hline PGD & $\begin{array}{l}100 \\
107\end{array}$ & $\begin{array}{l}0.886 \\
0.114\end{array}$ & $\begin{array}{c}1.000 \\
-\end{array}$ & $\begin{array}{c}1.000 \\
-\end{array}$ & $\begin{array}{c}1.000 \\
-\end{array}$ \\
\hline PGI-1 & $\begin{array}{r}85 \\
93 \\
100 \\
107 \\
115\end{array}$ & $\begin{array}{c}- \\
0.166 \\
0.816 \\
0.009 \\
0.009\end{array}$ & $\begin{array}{c}0.606 \\
0.369 \\
0.025 \\
- \\
-\end{array}$ & $\begin{array}{c}0.580 \\
0.420 \\
- \\
- \\
-\end{array}$ & $\begin{array}{c}0.490 \\
0.510 \\
- \\
- \\
-\end{array}$ \\
\hline PGI-2 & $\begin{array}{r}57 \\
100 \\
143 \\
157\end{array}$ & $\begin{array}{c}- \\
0.991 \\
0.009 \\
-\end{array}$ & $\begin{array}{c}0.271 \\
0.729 \\
- \\
-\end{array}$ & $\begin{array}{c}0.065 \\
0.935 \\
- \\
-\end{array}$ & $\begin{array}{c}0.060 \\
0.940 \\
- \\
-\end{array}$ \\
\hline PGM-1 & $\begin{array}{r}91 \\
100 \\
112 \\
115 \\
126\end{array}$ & $\begin{array}{c}0.105 \\
0.860 \\
0.035 \\
- \\
-\end{array}$ & $\begin{array}{c}- \\
- \\
0.148 \\
0.844 \\
0.008\end{array}$ & $\begin{array}{c}- \\
- \\
0.015 \\
0.985 \\
-\end{array}$ & $\begin{array}{c}- \\
- \\
- \\
0.600 \\
0.400\end{array}$ \\
\hline PGM-2 & $\begin{array}{r}58 \\
88 \\
100 \\
112 \\
117\end{array}$ & $\begin{array}{c}- \\
0.026 \\
0.719 \\
- \\
0.255\end{array}$ & $\begin{array}{c}- \\
0.025 \\
0.942 \\
0.008 \\
0.025\end{array}$ & $\begin{array}{c}- \\
0.015 \\
0.970 \\
- \\
0.015\end{array}$ & $\begin{array}{c}0.010 \\
- \\
0.990 \\
- \\
-\end{array}$ \\
\hline
\end{tabular}


Table 4. Pomatoschistus microps. Measures of allozyme variability in samples from the different sampling areas. $P_{95}$ : percentage of polymorphic loci at $95 \% ; A$ : mean number of allele per locus. $H_{0}$ : observed heterozygosity. $H_{\mathrm{e}}$ : expected unbiased heterozygosity under Hardy-Weinberg equilibrium

\begin{tabular}{|lccccc|}
\hline Area & $\begin{array}{c}\text { Sample } \\
\text { size }\end{array}$ & $\mathrm{P}_{95}$ & $A$ & $H_{\mathrm{o}}$ & $H_{\mathrm{e}}$ \\
\hline Salses-Leucate & 57 & 0.400 & 2.15 & 0.104 & 0.131 \\
Cadiz & 61 & 0.421 & 2.16 & 0.165 & 0.179 \\
Hendaye & 69 & 0.263 & 1.84 & 0.114 & 0.134 \\
Fehmarn & 50 & 0.263 & 1.53 & 0.093 & 0.119 \\
& & & & & \\
\hline
\end{tabular}

associations (multiple-comparison Tukey-type test, $\mathrm{p}<$ 0.01 ) (Table 6). Moreover, the volume of the cyst cavity and the volume of the excretory bladder were significantly larger for Salses-Leucate and Fehmarn samples than for Cadiz and Hendaye samples (multiple-comparison Tukey-type test, $\mathrm{p}<0.01$ ) (Table 6). Discriminant analysis of the cyst measurements revealed significant differences among all stations $(p<0.001)$ except between Cadiz and Hendaye $(p=0.058)$. A scatterplot of canonical scores (Fig. 3) highlighted a strong isolation of the sympatric association (SalsesLeucate) on Axis 1. The Fehmarn population was isolated on Axis 2. A Mantel test between genetic (Fig. 4a) and Mahalanobis (Fig. 4b) distances was significant $(\mathrm{r}=0.76 ; \mathrm{p}=0.04)$.

\section{DISCUSSION}

Our study compared the reaction of a naive host (Pomatoschistus microps) to a new strain of parasite with a local association of host-parasite system. This is close to Association 2 in our 'Introduction'. In our case,

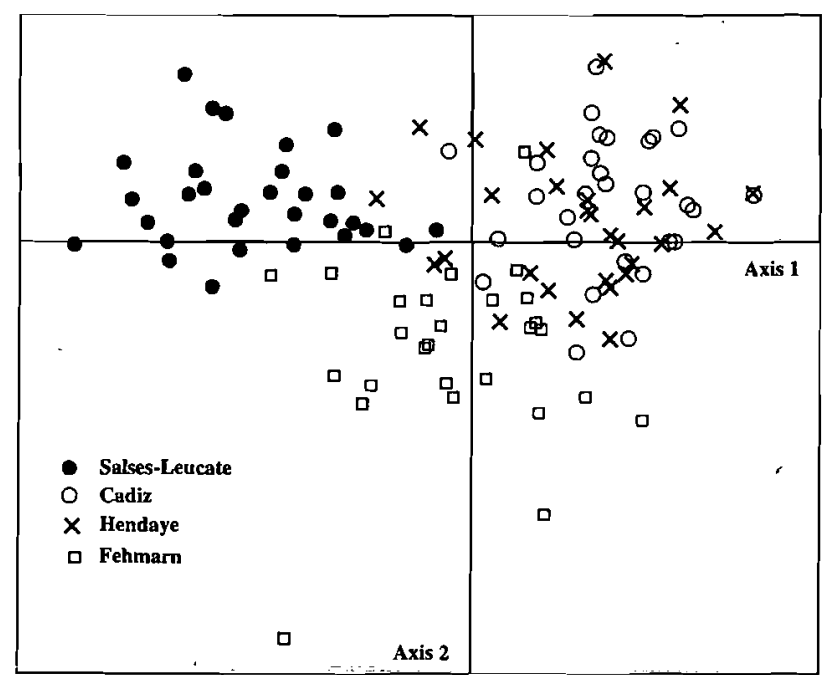

Fig. 3. Pomatoschistus microps. Discriminant analysis of individual histological measurements of metacercarial cysts for each sampling area

only the strain of parasite was new to the host species which (except for the Cadiz population) was naturally infested by this parasite species. Such a situation can be expected to occur often during the process of biological conservation, when species recolonize protected areas or when populations are displaced for aquaculture, or to increase genetic combinations.

\section{Genetic comparison}

The results of the genetic analysis indicate significant genetic variation among the 4 samples of Pomatoschistus microps. Such genetic differentiation was a prerequisite for our experiment, as geographic separa-

Table 5. Pomatoschistus microps. Estimation of deviation from Hardy-Weinberg expectation within samples $\left(F_{\mathrm{iS}}\right)$ and $\mathrm{p}$-values (significance of the estimation) calculated by Markov chain method. Bold: indicates significant deficiency of heterozygotes (low heterozygosity). - : absent

\begin{tabular}{|c|c|c|c|c|c|c|c|c|}
\hline \multirow[t]{2}{*}{ Locus } & \multicolumn{2}{|c|}{ Salses-Leucate } & \multicolumn{2}{|c|}{ Cadiz } & \multicolumn{2}{|c|}{ Hendaye } & \multicolumn{2}{|c|}{ Fehmarn } \\
\hline & $F_{\mathrm{IS}}$ & $\mathrm{p}$ & $F_{\mathrm{IS}}$ & $\mathrm{p}$ & $F_{\mathrm{IS}}$ & $p$ & $F_{\text {IS }}$ & p \\
\hline $\mathrm{ADA}$ & 0.005 & 0.02 & 0.02 & 0.23 & 0.01 & 0.04 & 0.025 & 0.54 \\
\hline GOT & -0.05 & 1 & - & - & - & - & - & - \\
\hline IDH & -0.01 & 1 & 0.12 & 0.08 & 0.37 & $<0.01$ & - & - \\
\hline MPI & 0.55 & 0.03 & 0.08 & 0.16 & 0.2 & 0.02 & 0.06 & 0.23 \\
\hline PEP B & - & - & 0.27 & 0.09 & . $\quad-$ & - & - & - \\
\hline PEP E & 0.37 & 0.01 & -0.01 & 1 & - & - & - & - \\
\hline PGD & 0.05 & 0.54 & - & - & - & - & - & - \\
\hline PGI1 & -0.14 & 0.90 & 0.05 & 0.40 & -0.01 & 0.61 & 0.09 & 0.36 \\
\hline PGI2 & - & - & 0.05 & 0.46 & 0.18 & 0.24 & 0.65 & $<0.01$ \\
\hline PGM1 & 0.30 & 0.01 & 0.27 & 0.03 & -0.01 & 1 & 0.67 & $<0.01$ \\
\hline PGM2 & 0.21 & 0.08 & 0.12 & 0.17 & -0.02 & 1 & - & - \\
\hline
\end{tabular}


Table 6. Pomatoschistus microps. Quantitative and qualitative results (means \pm SE) of experimental infestation. $N_{\mathrm{i}}=$ mean initial number of encysted metacercariae; $N_{+30}=$ mean number of encysted metacercariae after experimental infestation with 30 cercariae; $S_{\text {ind }}=$ mean percentage of individual infestation success $; I_{\mathrm{pop}}=$ mean percentage of infestation success at population level (taking into account fish that died during experiment, $D$ ); VM: metacercarial estimated volume $\left(10^{-3} \mathrm{~mm}^{3}\right) ; C C$ : cyst cavity estimated volume $\left(10^{-3} \mathrm{~mm}^{3}\right)$; Interf: interface width $\left(10^{-3} \mathrm{~mm}\right) ; D C$ : digestive caecum estimated volume $\left(10^{-4} \mathrm{~mm}^{3}\right)$; $E B:$ excretory bladder estimated volume $\left(10^{-4} \mathrm{~mm}^{3}\right)$; SE: standard error

\begin{tabular}{|lcrrrrrrrrl}
\hline Area & $N_{\mathrm{i}} \pm \mathrm{SE}$ & $N_{+30} \pm \mathrm{SE}$ & $S_{\text {ind }} \pm \mathrm{SE}$ & $I_{\text {pop }}(D)$ & $V M \pm \mathrm{SE}$ & $C C \pm \mathrm{SE}$ & $\operatorname{lnterf} \pm \mathrm{SE}$ & $D C \pm \mathrm{SE}$ & $E B \pm \mathrm{SE}$ \\
\hline Salses-Leucate & $13.6 \pm 3.6$ & $29.2 \pm 5.0$ & $39.9 \pm 9.4$ & 22.8 & $(12)$ & $4.9 \pm 0.3$ & $6.6 \pm 0.3$ & $10.2 \pm 0.4$ & $2.1 \pm 0.3$ & $7.7 \pm 0.8$ \\
Cadiz & $0 \pm 0$ & $11.0 \pm 1.3$ & $36.7 \pm 4.4$ & 36.7 & $(0)$ & $2.3 \pm 0.1$ & $3.5 \pm 0.2$ & $4.7 \pm 0.3$ & $2.0 \pm 0.3$ & $2.7 \pm 0.3$ \\
Hendaye & $3.9 \pm 1.3$ & $16.6 \pm 1.9$ & $41.0 \pm 6.2$ & 30.3 & $(7)$ & $2.5 \pm 0.2$ & $3.7 \pm 0.3$ & $5.2 \pm 0.3$ & $1.1 \pm 0.1$ & $4.1 \pm 0.6$ \\
Fehmarn & $1.0 \pm 0.5$ & $9.4 \pm 1.8$ & $29.0 \pm 5.7$ & $14.7(11)$ & $3.8 \pm 0.2$ & $6.7 \pm 0.4$ & $6.2 \pm 0.3$ & $2.6 \pm 0.6$ & $6.5 \pm 0.7$ \\
\hline
\end{tabular}

tion is not in itself sufficient to ensure local adaptation. Our results also revealed strong differentiation between the Mediterranean population and the other 3 populations. Two hypotheses could explain this: (1) It could be linked to the strong geographical isolation of the Mediterranean population, which is restricted mainly to enclosed coastal lagoons along the coast of France; this hypothesis could be confirmed by examining the genetic structure of populations in other lagoons in the southern part of France. (2) It might be a consequence of the paleobiogeographic history of the Mediterranean Sea during the last glaciation (Keigwin \& Thunnel 1979); the Pleistocene drop in the sea level would have resulted in isolation of the Mediterranean populations of $P$. microps, as has been demonstrated for other fish species (Quignard 1978, Tirard et al. 1992).

\section{Quantitative parasite success}

We found no quantitative difference in the success of parasite infection between the 4 host populations. This

a

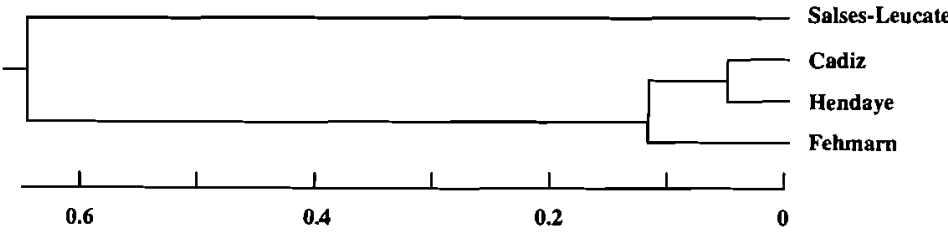

b

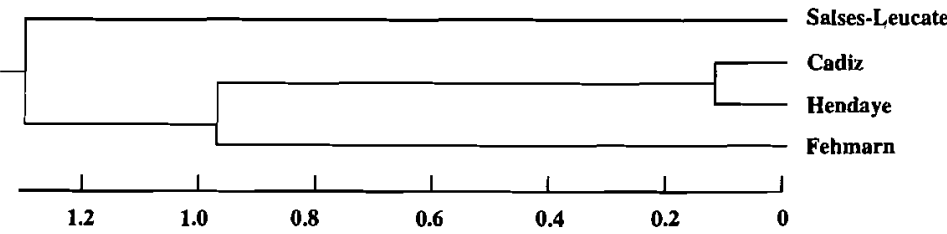

Fig. 4. Pomatoschistus microps. UPGMA dendrogram showing relationships between populations based on (a) genetic and (b) Mahalanobis distances, calculated using histological measurements of metacercarial cyst result may reflect a lack of heritability of host suitability and/or of parasite infectivity (Grosholz \& Ruiz 1995). Although it has been shown that this parasite species Labratrema minimus has a significant negative effect on its host's condition-factor (Faliex \& Morand 1994), it seems likely that such effect puts little selective pressure on the host. Therefore, long-term association would not have induced 'co-evolutionary' adaptation in parasite success between sympatric and allopatric crosses in each region to a measurably different extent. Moreover, differences in generation times between host and parasite (the parasite generally having the shorter generation time: Price 1980, Lively 1989) has been invoked as an alternative explanation for local adaptation. However, Pomatoschistus microps has a short life span of 2 yr (Miller 1975) that should not be very different from the life span of the parasite (Maillard 1976), making it much more difficult to detect any evolutionary advantage the parasite might have over its local host. Finally, as this parasite species is opportunistic (i.e. it usually parasitizes different host species as second intermediate hosts [Maillard 1976]), it may infect 'most exposed hosts, especially when these belong to genetically close species. The result would be a lack of a quantitative difference in infective success, in terms of the number of penetrating parasites, between the various host populations.

\section{Qualitative parasite success}

However, as a result of the opportunistic behaviour of this parasite species, its qualitative success should vary among (1) different host species the parasite is able to infest, and (2) genetically different entities of the same host species. When the digenean cercariae penetrate the host, the fish hepatic cells are stored in the digestive caecum. During metacercarial development, the digestive caecum volume de- 
creases and the wastes are collected in the excretive bladder of the metacercaria. The cyst wall is composed of 3 cell layers, of mixed origin (Faliex 1990), whose degree of infestation reflects the degree of interaction between host and parasite. Our results revealed a differential success of the parasite at the histological level: it is able to penetrate the host and to reach the liver, but it is unable to develop optimally in allopatric associations. This result seems to indicate a better relationship between sympatric parasite and host arising from a long-term association. A similar result was reported for a cestode of the striped bass (Sakanari \& Moser 1990). Such differential development of metacercarial cysts in the liver could have selective consequences for both host and parasite. For the host, lessdeveloped cysts would occupy less volume in the liver and might thus be less pathogenic; for the parasite, the survival of its second intermediate host would be indispensable to its own successful development prior to transfer to the final host.

\section{Parasitism and conservation}

Parasites are usually less well adapted and more virulent to a newly colonized host species (Toft \& Karter 1990, Ewald 1995). Thus, the recolonisation of protected areas by new host species or the translocation of individuals (accidentally or intentionally) into new locations together with their parasites may induce new host-parasite associations and represent threats to the survival of native host populations. In turn, introduced populations would be faced with native parasite populations that could respond in novel ways in terms of infectivity and virulence, and abort their recolonisation success. When it occurs, local adaptation of host-parasite systems should be an important factor affecting biological conservation, as the performance and population growth of the parasite should increase over time as it adapts to its new local host. Our results as well as those of earlier studies on other host-parasite systems (Vera et al. 1990, Ballabeni \& Ward 1993, Ebert 1994, Lively \& Jokela 1996) seem to contradict the hypothesis of high virulence in new host-parasite associations, and indicate a need to reconsider the potential risk of introducing parasites with recolonizing host species. Nevertheless, the response of the host-parasite system will depend upon the structure of both host and parasite populations. For example, when host populations are isolated by distances or barriers sufficient to prevent parasite dispersal, gene flow may effect local differentiation between populations of both host and parasite (Mopper 1998). Moreover, fragmented host populations, arising either from translocation of individuals to new sites or from low densities of a rare or endangered species, will provide but a patchy environment for a parasite. This will reduce parasite gene flow and favor local adaptation (Peterson \& Denno 1998). Such local adaptation of a parasite, when/if it occurs, should increase the likelihood of differential compatibility in allopatric pairings of host and parasite, and result in a longer term disequilibrium of the association. Populations of endangered species will be fragmented in isolated protected zones, and this should prove important in limiting the spread of any epidemic diseases that may occur (Dobson \& May 1986, Packer et al. 1991).

Finally, lack of evidence of serious harm to their hosts by introduced parasite species does not automatically imply the absence of any deleterious effect (Mills et al. 1993), it merely underlines the limitations of our knowledge on the subject. It has long been thought that parasitic virulence results from misadaptation of the parasite to its host; this view of the host-parasite relationship has evolved during recent years (Bull 1994, Ebert 1994, Ewald 1995).

Acknowledgements. This work was financially supported by the Conseil Règional du Languedoc Roussillon, the Programme National sur le Dèterminisme du Recrutement (PNDR), the French Ministère de l'Enseignement Supérieur et de la Recherche and the CNRS. The authors would like to thank Drs Thierry DeMeeüs and François Renaud for helpful comments during the first part of the study, and Pr. Peter Sale for constructive suggestions on the first draft of this manuscript. We are also very grateful to Marie-Thérèse Alméras for technical assistance in the histological work. The collection of fish from the various stations would not have been possible without the help of Dr Zander in Fehmarn and of Drs Nieto and Alberto in Cadiz.

\section{LITERATURE CITED}

Ballabeni P, Ward PI (1993) Local adaptation of the trematode Diplostomum phoxini to the European minnow Phoxinus phoxinus, its second intermediate host. Funct Ecol 7 : $84-90$

Bauer ON, Hoffman GL (1976) Helminth range extension by translocation of fish. In: Page LA (ed) Wildlife diseases. Plenum Press, New York, p 163-172

Belkhir K, Borsa P, Goudet J, Chikhi L, Bonhomme F (1996) Genetix v3.0, logiciel sous Windows TM pour la génétique des populations. Laboratoire Génome et Populations, CNRS UPR 9060, Université Montpellier 2

Briskie JV, Sealy SG, Hobson KA (1992) Behavioral defenses against avian brood parasitism in sympatric and allopatric host populations. Evolution 48:334-340

Bull JJ (1994) Perspective: virulence. Evolution 48:399-405

Calvo-Ugarteburu G, McQuaid CD (1998) Parasitism and introduced species: epidemiology of trematodes in the intertidal mussels Perna perna and Mytilus galloprovincialis. J Exp Mar Biol Ecol 220:47-65

Carroll SP, Boyd C (1992) Host race radiation in the soapberry bug: natural history with the history. Evolution 46: 1052-1069

Claessen D, de Roos AM (1995) Evolution of virulence in a 
host-pathogen system with local pathogen transmission Oikos 74:401-413

Combes C, Le Brun N (1990) lnvasions by parasites in continental Europe. In: di Castri F, Hansen AJ, Debussche M (eds) Biological invasions in Europe and the Mediterranean Basin. Kluwer Academic Publishers, Dordrecht, p 285-296

Dobson AP, May RM (1986) Disease and conservation. ln: Soule ME (ed) Conservation biology. The science of scarcity and diversity. Sinauer Associates, inc, Sunderland, MA, p 345-366

Dufour V, Jouvenel JY, Galzin R (1995) Study of a Mediterranean reef fish assemblage. Comparisons of population distributions between depths in protected and unprotected areas over one decade. Aquat Living Resour 8: $17-25$

Dufva R (1996) Sympatric and allopatric combinations of hen fleas and great tits: a test of a local adaptation hypothesis. J Evol Biol 9:505-510

Dwyer G, Levin SA, Buttel L (1990) A simulation model of the population dynamics and evolution of myxomatosis. Ecol Monogr 60:423-447

Ebert D (1994) Virulence and local adaptation of a horizontally transmitted parasite. Science 265:1084-1086

Ewald PW (1995) The evolution of virulence: a unifying link between parasitology and ecology. J Parasitol 81:659-669

Faliex E (1990) Experimental infection of juveniles grey mullet, Liza ramada, by metacercaria of Labratrema minimus (Digenea: Bucephalidae). Ultrastructural analysis of the host parasite relationship. ln: Perkins FO, Cheng TC (eds) Pathology in marine science. Academic Press, London, p 299-303

Faliex E, Morand S (1994) Population dynamics of the metacercarial stage of the bucephalid trematode, Labatrema minimus (Stossich, 1887) from Salses-Leucate lagoon (France) during the cercarial shedding period. J Helminth 68:35-40

Francour P (1994) Pluriannual analysis of the reserve effect on ichthyofauna in the Scandola natural reserve (Corsica, Northwestern Mediterranean). Oceanol Acta 173:309-317

Frank SA (1994) Recognition and polymorphism in host-parasite genetics. Phil Trans R Soc Lond (Ser B: Biol Sci) 346: 283-293

Gandon S, Capowiez Y, Dubois Y, Michalakis Y, Olivieri 1 (1996) Local adaptation and gene for gene coevolution in a metapopulation model. Proc R Soc Lond (Ser B: Biol Sci) 263:1003-1009

Grosholz ED, Ruiz GM (1995) Does spatial heterogeneity and genetic variation in populations of the xanthid crab Rhithropanopeus harrisii (Gould) influence the prevalence of an introduced parasitic castrator? J Exp Mar Biol Ecol 187:129-145

Hamilton WD (1993) Haploid dynamic polymorphism in a host with matching parasites: effects of mutation, subdivison, linkage and patterns of selection. J Hered 84:328-338

Harmelin JG (1987) Structure et variabilité de l'ichtyofaune d'une zone rocheuse protégée en Méditerranée (Parc National de Port-Cros, France). PSZN 1: Mar Ecol 8: 263-284

Hoffman GL (1970) lntercontinental and transcontinental dissemination and transfaunation of fish parasites with emphasis on whirling disease (Myxosoma cerebralis). Symposium on diseases of fishes and shellfishes. Am Fish Soc Symp 5:69-89

Keigwin LD, Thunell RC (1979) Middle Pliocene climatic change in the western Mediterranean from faunal and oxygen isotopic trends. Nature 282:292-296
Kennedy CR (1993) Introductions, spread and colonization of new localities by fish helminth and crustacean parasites in the British Isles: a perspective and appraisal. J Fish Biol 43:287-301

Kennedy CR (1994) The ecology of introductions. In: Pike AW, Lewis JW (eds) Parasitic diseases of fish. Samara Publishing, London, p 189-208

Kleiman DG (1989) Reintroduction of captive mammals for conservation. Bioscience 39:152-161

Konstant WR, Mittermeier RA (1982) Introduction, reintroduction and translocation of neotropical primates: past experiences and future possibilities. Int $\mathrm{ZoO} \mathrm{Yb}$ 22:69-77

Lindburg DG (1992) Are wildlife reintroductions worth the cost? Zoo Biol 11:1-2

Lively CM (1989) Adaptation by a parasitic trematode to local populations of its snail host. Evolution 44:1663-1671

Lively CM, Jokela J (1996) Clinal variation for local adaptation in a host parasite interaction. Proc R Soc Lond (Ser B: Biol Sci) 263:891-897

Lodge DM, Stein RA, Brown KM, Covich AP, Bronmark C,

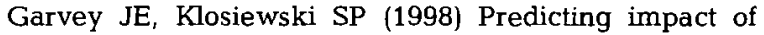
freshwater exotic species on native biodiversity: challenges in spatial scaling. Aust J Ecol 23:53-67

Maillard C (1976) Distomatoses de poissons en milieu lagunaire. $\mathrm{PhD}$ thesis, Universite Montpellier

Mantel N (1967) The detection of disease clustering and generalized regression approach. Cancer Res 27:209-220

Martoja R, Martoja M (1967) Initiation aux techniques de l'histologie animale. Masson \& Cie, Paris

McCallum H, Dobson A (1995) Detecting disease and parasite threats to endangered species and ecosystems. Trends Ecol Evol 10:190-194

Miller PJ (1975) Age, structure and life-span in the common goby Pomatoschistus microps. J Zool Lond 177:425-448

Mills EL, Leach JH, Carlton JT, Secor CL (1993) Exotic species in the Great Lakes: a history of biotic crises and anthropogenic introductions. J Great Lakes Res 19:1-54

Minckley WL (1995) Translocation as a tool for conserving imperilled fishes: experiences in Western United States. Biol Conserv 72:297-309

Mopper S (1998) Local adaptation and stochastic events in an oak leaf-miner population. In: Mopper S, Strauss SY (eds) Genetic structure and local adaptation in natural insect populations: effects of ecology, life history, and behavior. Chapman \& Hall, New York, p 139-155

Morand S, Manning SD, Woolhouse MEJ (1996) Parasite host coevolution and geographic patterns of parasite infectivity and host susceptibility. Proc R Soc Lond (Ser B: Biol Sci) 263:119-128

Moravec F (1992) Spreading of the nematode Anguillicola crassus (Dracunculoidea) among eel populations in Europe. Folia Parasitol 39:247-248

Moyle PB, Leydy RA (1992) Loss of biodiversity in aquatic ecosystems: evidence from fish fauna. In: Fiedler PL, Jain SK (eds) Conservation biology. The theory and practice of nature conservation. Preservation and management. Chapman \& Hall, New York, p 127-169

Packer $C$, Pusey AE, Rowley $H$, Gilbert D, Martenson JA, O'Brien SJ (1991) Case study of a population bottleneck: lions of the Ngorongoro crater. Conserv Biol 5:219-230

Pasteur N, Pasteur G, Bonhomme F, Catalan J, Britton-Davidian J (1987) Manuel technique de génétique par électrophorèse des protéines. Techniques et documentation. Lavoisier, Paris

Peterson MA, Denno RF (1998) Life-history strategies and the genetic structure of phytophagous insect populations. In: Mopper S, Strauss SY (eds) Genetic structure and local 
adaptation in natural insect populations: effects of ecology, life history, and behavior. Chapman \& Hall, New York, p 139-155

Price PW (1980) Evolutionary biology of parasites. Princeton University Press, Princeton, NJ

Quignard JP (1978) Introduction à l'ichthyologie méditerranéenne: aspect général du peuplement. Bull Off Natn Pêch Tunisie 2:3-21

Raymond M, Rousset F (1995) GENEPOP (Version 1.2): population genetics software for exact tests and eucumenicism. J Hered 86:248-249

Reynolds J, Weir BS, Cockerham CC (1983) Estimation of the coancestry coefficient: basis for a short-term genetic distance. Genetics 105:767-779

Sakanari JA, Moser M (1990) Adaptation of an introduced host to an indigenous parasite. J Parasit 76:420-423

Scott ME, Dobson A (1989) The role of parasites in regulating host abundance. Parasitol Today 5:176-183

Shaklee JB, Allendorf FW, Morizot DC, Whitt GS (1990) Gene nomenclature for protein-coding loci in fish. Trans Am Fish Soc 119:2-15

Sneath PHA, Sokàl RR (1973) Numerical taxonomy-the principles and practice of numerical classifiction. WH Freeman \& Co, San Francisco

Editorial responsibility: Otto Kinne (Editor), Oldendorf/Luhe, Germany
Soler M, Møller AP (1990) Duration of sympatry and coevolution between the great spotted cuckoo and its magpie host. Nature 343:748-750

Tirard C, Berrebi P, Raibaut A, Renaud F (1992) Parasites as biological markers: evolutionary relationships in the heterospecific combination of helminths (monogeneans) and teleosts (Gadidae). Biol J Linn Soc 47:173-182

Toft CA, Karter AJ (1990) Parasite-host coevolution. Trends Ecol Evol 5:326-329

Vera C, Jourdane J, Selin B, Combes C (1990) Genetic variablity in the compatibility between Schistosoma haematobium and its potential vectors in Niger. Epidemiological implications. Trop Med Parasitol 141:121-224

Viggers KL, Lindenmayer DB, Spratt DM (1993) The importance of disease in reintroduction programmes. Wildl Res 20:687-698

Wallis GP, Beardmore JA (1984) Genetic variation and environmental heterogeneity in some closely related goby species. Genetica 62:223-237

Whitehead PJP, Bauchot ML, Hureau JC, Nielsen J, Tortonese E (1986) Check-list of the fishes of the North-Eastern Atlantic and of the Mediterianean. UNESCO, Paris

Zar JH (1984) Biostatistical analysis, 2nd edn. Prentice Hall, Englewood Cliffs, NJ

Submitted: May 20, 1999; Accepted: November 4, 1999 Proofs received from author(s): May 15, 2000 